удК 655.226.5

() С. Ф. Гавенко, д.т.н., професор, В. В. Бернацек, к.т.н., доцент, М. Т. Лабецька, к.т.н., асистент, Українська академія друкарства, Львів, Україна

\title{
ДОСЛІДЖЕННЯ ВПЛИВУ ОФСЕТНИХ ДРУКАРСЬКИХ ФОРМ СТР НА РЕПРОДУКЦІЙНО-ГРАФІЧНІ ПОКАЗНИКИ ВІДБИТКІВ
}

В роботі досліджено репродукційно-графічні показники друкарських форм виготовлених за технологією CtP популярних марок, які представлені на Українському ринку поліграфічних витратних матеріалів. В результаті досліджень було побудовано графічні залежності, які дозволяють оцінити якість відтворення кольорового зображення віддрукованого офсетним способом друку при заданих умовах та визначити максимальну відповідність до оригіналу.

Ключові слова: репродукційно-графічні показники; CtP; офсетний друк; офсетна пластина; кольорове зображення.

Постановка проблеми

Офсетний друк, як і раніше, посідає провідні позиції серед відомих способів відтворення поліграфічної продукції. Домінантність даного способу можна пояснити наявністю на ринку високопродуктивного та технологічно гнучкого друкарського устаткування; появою нових поліграфічних матеріалів (паперів, фарб, декельних і формних пластин); впровадженням гнучких і ефективних варіантів формного виробництва. Одним із таких є використання технології «Computer-toPlate», яка суттєво зміцнила позиції офсетного друку завдяки можливості істотного скорочення тривалості процесу виготовлення друкарських форм (через відсутність процесу виготовлення фотоформ), високим показникам їх якості (внаслідок знижен- ня рівня спотворень, які виникають при виготовленні фотоформ), зменшенню кількості обладнання та персоналу, економії фотографічних матеріалів і обробних розчинів та екологічності процесу [1-4].

Згідно технології CtP у пристрій запису подаються формні пластини, що знаходяться в світлозахисних касетах. Формна пластина кріпиться на барабані і записується лазерним променем. Далі експонована пластина через транспортер подається в проявний пристрій. Тобто, система повністю автоматизована.

Конструкції апаратів сучасних CtP систем розділяють на:

- барабанні:

а) апарати з внутрішнім барабаном (форма розташована на внутрішній поверхні нерухомого циліндра); 
б) апарати з зовнішнім барабаном (форма розташована на зовнішній поверхні циліндра, що обертається).

- планшетні (форма розташована нерухомо в горизонтальній площині або робить рух у напрямку, перпендикулярному напрямку запису зображення).

Порівняно з аналоговою технологією, computer-to-plate дозволяє відтворювати елементи зображення менших розмірів, що значно збільшує кількість градацій, поліпшує відтворення і дрібних елементів: при великому тиску не відбувається заповнення пробілів на формі фарбою. Істотною перевагою використання цифрової технології є можливість отримання друкарських елементів з гіперболічною формою бічних граней (на відміну від трапецієподібного профілю на аналогових пластинах). Завдяки цьому стабілізується величина розтискування під час друку. Загальне зниження розтискування в півтонах при відтворенні растрових зображень досягає $10 \%$. Застосування цифрової технології дозволяє більш якісно відтворювати складні зображення $[5,6]$.

Як відомо, якість друкарських форм оцінюють через репродукційно-графічні показники, на які в свою чергу впливають параметри копіювального шару, мікрогеометрія поверхні підкладки формної пластини, умови експонування/проявлення, лініатура растру.

Репродукційно-графічні показники друкарських форм дозволяють оцінити якість відтворення деталей растрового і штрихового зображення. Це такі показники, як: роздільна здатність (характеризує відтворення дрібних деталей зображення і оцінюється кількістю ліній на одиницю довжини, які відтворюються на друкарській формі), видільна здатність (характеризує можливість передавати окремі штрихи, поряд з якими немає інших елементів і оцінюється шириною мінімально відтворюваного штриха), градаційна передача тонового зображення (характеризує якість відтворювання тонових або растрових зображень і оцінюється графічними залежностями).

Засобом для контролю якості форм є контрольні тест-об'єкти. Вони представлені в цифровому вигляді і містять ряд фрагментів різного цільового призначення для візуального та інструментального контролю (рис. 1, 2).

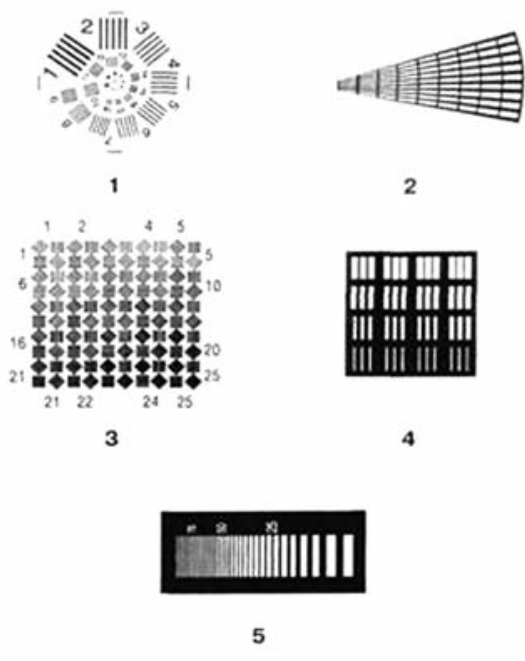

Рис. 1. Міри для визначення роздільної здатності копіювальних шарів і їх структури: 1 - колова; 2 - віялоподібна; 3 - прямокутна, орієнтована в різних напрямах;

$$
\text { 4, } 5 \text { - прямокутна }
$$


Після запису тест-об'єкту на копіювальний шар формної пластини і проведення відповідної обробки контролюються такі параметри як розмір відтворюваних штрихів елементів та інтервал градацій. Застосування цифрової технології дає можливість більш якісно відтворювати складні текстові та ілюстраційні зображення оригіналів 3 використанням комп'ютерної техніки [7-9].

\section{Мета роботи}

Визначення репродукційнографічних показників офсетних відбитків з друкарських форм, виготовлених за технологією CtP та оцінювання точності відтворення їх кольорового зображення.

\section{Результати проведених досліджень}

Об'єктами дослідження було обрано оригінал-макет зображення живої природи, який передає широкий спектр і велику гамму кольорів. Цифрова кольоропроба була віддрукована на струминному принтері EPSON Stylus ${ }^{\circledR}$ Pro 4880 на високоякісному півматовому папері для кольоропроб - epson standard proofing paper (205) 17". Друк аналогової кольоропроби здійснювали фар- бами Huber Group cepiï Resista на друкарській офсетній машині Heidelberg Printmaster GTO 52-2P з використанням трьох комплектів пластин відомих виробників № 1 - Ipagsa Industrial S.L. (Icпанія), № 2 - Vela Verona Lastre srl (Італія) і № 3 - Lastre Alloy ${ }^{\mathrm{TM}}$ Thermal Blue (Китай), характеристика яких наведена в таблиці. Лазерне експонування термальних офсетних пластини здійснювали на машині Plate Rite 8000 II. Друкарські відбитки отримували на крейдованому глянцевому папері Vega gloss масою $1 \mathrm{M}^{2} 115$ г.

Проведення експериментальних досліджень здійснювали згідно міжнародних стандартів: ISO 13655 - зміни кольору; ISO 3664 - умови нормалізованого спостереження; ISO 2846-2 стандарти на тріаду CMYK; ISO 12647-2 - нормативи на колірні показники тріадних фарб для офсетного друку; ISO 12647-4 нормативи на цифрову кольоропробу.

Для оцінювання якості відбитків було використано тестову шкалу з полями півтонів і тонів, яка побудована для CMYK-кольорів, як окремо для кожного кольоpy $(10,20,30,40,50,60,70,80$, 90, 100 \% насичення) так і при

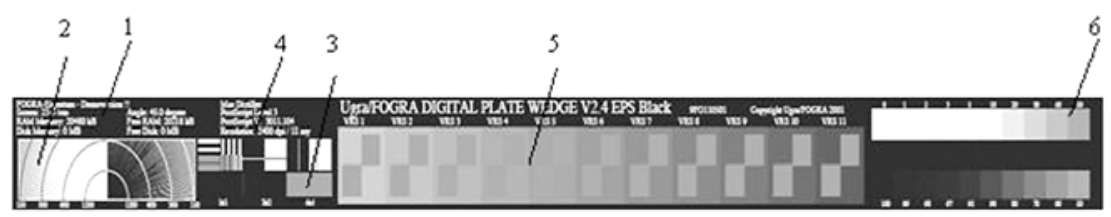

Рис. 2. Тест-об'єкт UGRA/FOGRA Digital Plate Control Wedge: 1 - інформаційне поле; 2 - поля для контролю роздільної здатності; 3 - поля для контролю фокусування; 4 - поля геометричної діагностики; 5 - поля для візуального контролю експозиції; 6 - поля для контролю відтворення градацій тонів зображення 
накладанні 100 \% полів попарно та тріадно СМY, згідно з міжнародним стандартом ISO 12647 , а також ряд шкал для контролю якості офсетного способу друку UGRA/FOGRA Digital Print Scale Control, які включають елементи ковзання, розтискування, відтворення дрібних деталей, радіальної міри, поля півтонів, суміщення фарб, текстові елементи і т.д. Оскільки у процесі друкування неперервні тони створюються з допомогою растрових крапок, у роботі використано одночасне поєднання регулярного (лініатура растра 150, 175 та 200 Ірі) та стохастичного растрування. Якість процесу репродукування контролювали за допомогою денситометра X-Rite 518.

На основі статистичної обробки результатів експериментальних досліджень було побудовано

Характеристики офсетних пластин

\begin{tabular}{|c|c|c|c|}
\hline Марка пластини & $\begin{array}{c}\text { Arte Ip-21 (Olte U- } \\
\text { 08), Ipagsa Industrial } \\
\text { S.L. (Іспанія) }\end{array}$ & $\begin{array}{l}\text { Lth-100, Vela Verona } \\
\text { Lastre SRL. (Італія) }\end{array}$ & $\begin{array}{c}\text { Lastre Alloy } \\
\text { Thermal Blue (Китай) }\end{array}$ \\
\hline $\begin{array}{l}\text { Товщина пластин, } \\
\text { мм }\end{array}$ & $\begin{array}{c}\text { стандарт - 0,15/ } \\
\text { 0,20/0,30/0,40; } \\
\text { на замовлення - } \\
0,24 / 0,50\end{array}$ & $\begin{array}{c}\text { стандарт - 0,15/ } \\
\text { 0,20/0,30/0,40/0,50; } \\
\text { на замовлення - } \\
\text { 0,24 }\end{array}$ & $\begin{array}{l}\text { стандарт - } \\
0,15 / 0,25 / 0,30\end{array}$ \\
\hline $\begin{array}{l}\text { Колір світлочут- } \\
\text { ливого шару }\end{array}$ & \multicolumn{3}{|c|}{ синій } \\
\hline $\begin{array}{l}\text { Контраст після } \\
\text { проявлення }\end{array}$ & \multicolumn{3}{|c|}{ високий } \\
\hline $\begin{array}{l}\text { Чутливість до } \\
\text { денного світла } \\
\text { та UV }\end{array}$ & \multicolumn{3}{|c|}{$\begin{array}{c}\text { експозиція протягом двох годин при денному світлі } \\
\text { не змінює характеристик світлочутливого шару }\end{array}$} \\
\hline $\begin{array}{l}\text { Спектральна } \\
\text { чутливість, нм }\end{array}$ & \multicolumn{3}{|c|}{ 800-850, пік чутливості - 830} \\
\hline $\begin{array}{l}\text { Використання } \\
\text { в СТР системах }\end{array}$ & \multicolumn{3}{|c|}{ із зовнішнім або внутрішнім барабаном та капстанових } \\
\hline $\begin{array}{l}\text { Необхідна } \\
\text { енергія, мДж/см² }\end{array}$ & 140 & \multicolumn{2}{|c|}{$140-160$} \\
\hline $\begin{array}{l}\text { Відтворення } \\
\text { растру }\end{array}$ & $\begin{array}{c}\text { 0,5-99\% } \\
\text { при } 450 \text { Ірі }\end{array}$ & $\begin{array}{c}1-99 \% \\
\text { при } 250 \text { Iрі }\end{array}$ & $\begin{array}{c}1-99 \% \\
\text { при } 200 \text { Iрі }\end{array}$ \\
\hline $\begin{array}{l}\text { Роздільна } \\
\text { здатність }\end{array}$ & \multicolumn{2}{|c|}{$\begin{array}{c}\text { до } 3200 \text { dрі та стохастичне } \\
\text { растрування }\end{array}$} & $\begin{array}{c}\text { стохастичне } \\
\text { растрування: } \\
20 \text { мкм }\end{array}$ \\
\hline Проявник & $\begin{array}{l}\text { Ipagsa IP-46, } \\
\text { Ipagsa PD-30 }\end{array}$ & DEV-CTP 100 & $\begin{array}{l}\text { Kodak Goldstar } \\
\text { Premium, DEV- } \\
\text { CTP 100, IP-46, } \\
\text { PD-30 }\end{array}$ \\
\hline $\begin{array}{l}\text { Температура } \\
\text { проявника, }{ }^{\circ} \mathrm{C}\end{array}$ & $23 \pm 1$ & $23-24 \pm 1$ & $22-24 \pm 1$ \\
\hline $\begin{array}{l}\text { Час проявлення, } \\
\text { с }\end{array}$ & $30 \pm 5$ & $25-40$ & $20-40$ \\
\hline
\end{tabular}


графічні залежності градаційної передачі фарб кольоропроби та офсетних відбитків при друкуванні трьома різними комплектами форм. Аналіз отриманих залежностей показав, що градаційна передача блакитної фарби досліджуваних комплектів пластин (рис. 3, а) при лініатурі растру 150 Ірі більш-менш відповідає кольоропробі в світлих ділянках, в півтонах оптична густина взірця № 3 починає зростати і тенденція продовжується в темних ділянках і знижується для взірця № 1, починаючи з півтонів до темних ділянок. Найбільш наближена до кольоропроби оптична густина у взірця № 2. Аналогічна картина спостерігається і для градаційної передачі блакитної фарби при лініатурі растру 175 Ірі (рис. 3, б). Так, для взірця № 3 спостерігається більш різке зростан-

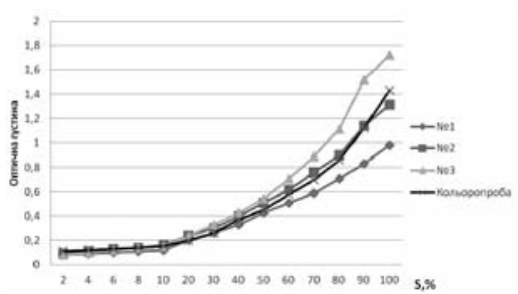

a

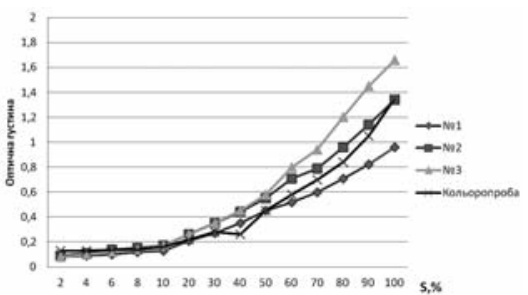

B ня оптичної густини в темних ділянках, а найбільша відповідність градації кольоропроби у взірця № 2.

На рис. 3, в оптичні густини досліджуваних взірців ведуть себе аналогічно кольоропробі в світлих ділянках, в півтонах спостерігається незначне збільшення густини у взірців № 2 і № 3. В темних ділянках оптична густина різко зростає у взірця № 3 і дещо знижується у взірця № 1. У взірця № 2 при $100 \%$ оптична густина співпадає із кольоропробою.

Розглядаючи градаційну передачу оптичної густини блакитної фарби для стохастичного растрування (рис. 3, г), можна помітити, що у світлих ділянках досліджувані пластини показують подібний результат до кольоропроби. В півтонах оптична густина зростає у всіх взірців, най-



б

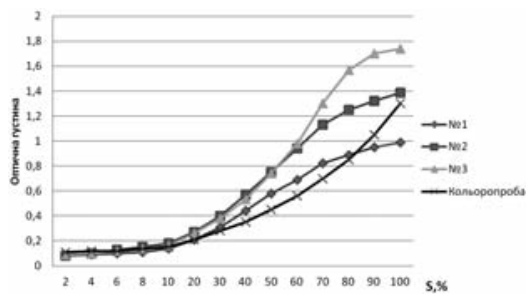

$\Gamma$

Рис. 3. Градаційна передача блакитної фарби (cyan) досліджуваних пластин № 1, № 2, № 3 при лініатурі растру: a -150 Ірі, б - 175 Ipi, в - 200 Iрі, г - стохастичному раструванні 
менше у взірця № 1. В темних ділянках найближчими до кольоропроби $є$ показники взірця № 1, хоча і взірець № 2 про $100 \%$ має наближені значення до кольоропроби.

На рис. 4, а представлено графіки залежності для пурпурної фарби при лініатурі растру 150 Ірі. У світлих ділянках видно незначне, в межах норми, зменшення густини досліджуваних пластин. В півтонах спостерігається зменшення густини для взірців № 1 та № 3, майже повне співпадання у № 2, і різке зниження густини в темних ділянках у взірців № 1 і № 3. Найбільш наближена градація у взірця № 2 .

В світлих ділянках для лініатури растру 175 Ірі, як показано на рис. 4, б, характер кривих знаходиться в межах норми. В півтонах видно незначне збільшен- ня густини у взірця № 2 і зменшення у взірця № 1 з подальшим зниженням в тінях. Приблизно однаково ведуть себе взірці № 2 і № 3 в темних ділянках, їх значення наближені до кольоропроби.

При лініатурі растру 200 Ірі (рис. 4, в) незначне зменшення оптичних густин в світлих ділянках спостерігається для всіх взірців. Однаковий характер кривих в півтонах і тонах показують взірці № 2 і № 3. Зменшення густини спостерігається у взірця № 1.

Незначне зменшення оптичних густин в світлих ділянках визначається для всіх взірців при стохастичному раструванні (рис. 4, г). Різке збільшення градації помітне в півтонах у взірця № 2, в той час, як № 1 i № 3 показують рівний результат і від-

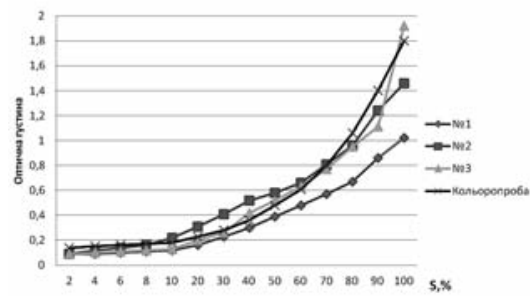

б

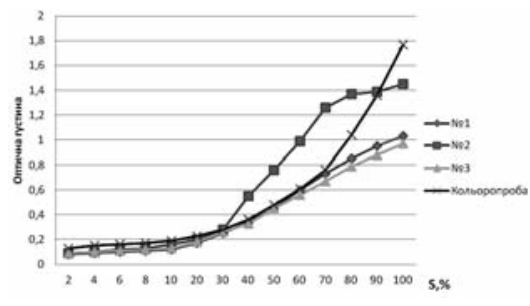

$\Gamma$

Рис. 4. Градаційна передача пурпурної фарби (magenta) досліджуваних пластин № 1, № 2, № 3 при лініатурі растру: a - 150 Ipi, б - 175 Ipi, в - 200 Ipi, г- стохастичному раструванні 
повідність кольоропробі. В темних ділянках оптична густина взірців № 1 та № 3 знижується, а взірець № 2 в точці 1,4 показує рівний результат.

Градаційна передача жовтої фарби при лініатурі растру 150 Ipi для всіх досліджуваних взірців пластин (№ 1-3) практично однакова і відповідає кольоропробі в світлих ділянках з незначним зменшенням густин в півтонах і темних ділянках. Аналогічна картина спостерігається і для лініатури растру 175 Ірі, в межах норми зменшення густини для всіх взірців в світлих ділянках і півтонах. Незначне зменшення густини спостерігається в темних ділянках (рис. 5, а, б).

При лініатурі растру 200 Ірі (рис. 5, в) для всіх взірців № 1-3 характер кривих передачі градації жовтої фарби найбільш наближений до градацій кольоропроби. При стохастичному раструванні (рис. 5, г) видно, що однаковий результат в світлих ділянках змінюється зростанням в півтонах для всіх взірців, причому найбільше у взірця № 3, і зменшенням густини в темних ділянках на всіх кривих.

Градаційна передача чорної фарби для всіх досліджуваних зразків (рис. 6) відповідає кольоропробі у світлих ділянках, спостерігається незначний ріст густини в півтонах у взірців № 2 і № 3. Дещо менше зростає густина у взірця № 1 і співпадає з густиною кольоропроби при максимальній площі растрового елементу 100 \% для взірців № 2 і № 3. Найбільше наближення до кольоропроби спостерігається у взірця № 1.

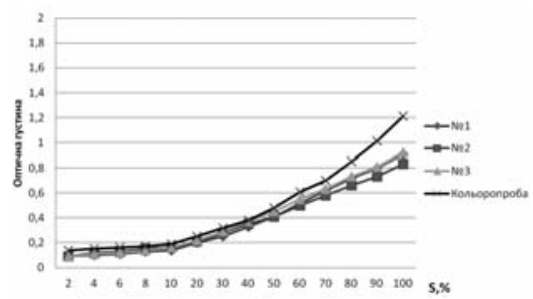

б



$\Gamma$

Рис. 5. Градаційна передача жовтої фарби (yellow) досліджуваних пластин № 1, № 2, № 3 при лініатурі растру: a - 150 lpi, б - 175 lpi, в - 200 Iрі, г - стохастичному раструванні 


\section{Висновки}

У результаті експериментальних досліджень друкованих відбитків з використанням термальних офсетних пластин отримані такі результати кольоропередачі зображень:

- для блакитної фарби оптична густина зображення є максимально наближеною до кольоропроби у зразка № 2 при усіх досліджуваних лініатурах растру та у зразка № 1 у випадку стохастичного растрування;

- для пластин № 2 та № 3 не виявлено суттєвої різниці у градаційній передачі пурпурної фарби при регулярному раструванні, оскільки отримано практично однакові показники оптичної густини плашок, контрасту та насиченості зображення, тоді як при стохастичному раструванні показники густини збігаються лише у світлих ділянках;

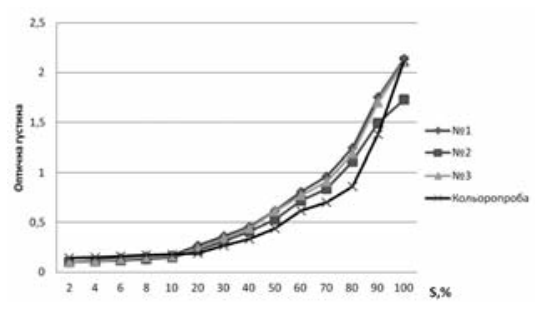

a



B
- спостерігаються незначні відхилення густини при регулярному раструванні для жовтої фарби та практично ідеальне співпадіння при стохастичному раструванні для трьох комплектів форм;

- позитивний результат виявлено у досліджуваних пластин при всіх лініатурах растру для чорної фарби, проте починаючи із ділянок півтонів спостерігаються відхилення від кольоропроби при стохастичному раструванні.

Аналіз порівняння тоновідтворення в системі «кольопробадрукований відбиток» показав незначні, візуально не помітні відхилення. Разом із тим для високохудожніх робіт рекомендується використання стохастичного растрування, яке враховує множину крапок, потрібних для відображення необхідної інтенсивності тону в комірці растра.

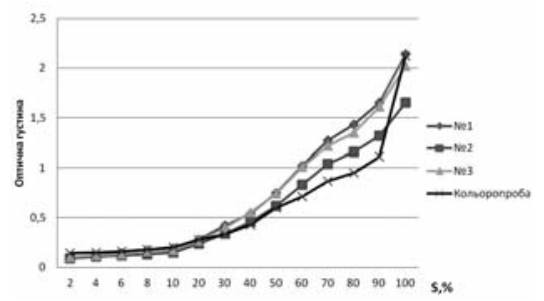

б

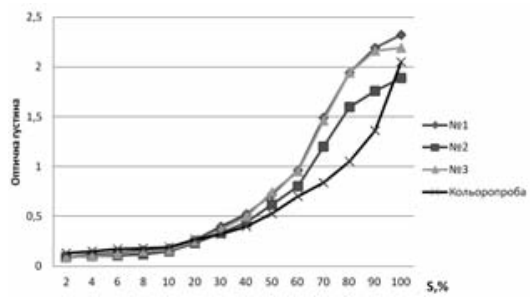

$\Gamma$

Рис. 6. Градаційна передача чорної фарби (black) досліджуваних пластин № 1, № 2, № 3 при лініатурі растру: a - 150 lpi, б - 175 Ipi, в - 200 Ірі, г - стохастичному раструванні 


\section{Список використаної літератури}

1. Полянский Н. Н. Технология формных процессов / Н. Н. Полянский, О. А. Карташева, Е. Б. Надирова. - М. : МГУП, 2010. - С. 366.

2. Карташева О. А. Цифровые технологии формных процессов плоской офсетной печати / О. А. Карташева, Е. В. Бушева, Е. Б. Надирова. Москва : МГУП, 2013. - 71 с.

3. Грибков А. В. Техника полиграфического производства. Часть 2. Допечатное оборудование / А. В. Грибков, Ю. Н. Ткачук. - Москва : МГУП, 2010. $-254 \mathrm{c}$.

4. ISO 12647-2: 2004 / Amd 1: 2007 - Управління процесами виробництва кольороподілених напівтонових зображень, пробних і накладних відбитків - Частина 2: Офсетний аркушевий друк.

5. Горошко О. Система контролю якості друкарського процесу / О. Горошко, О. Козак // Палітра друку. - 2000. - № 6. - С. 54-57.

6. Гавенко С. Ф. Системотехнический анализ и управление качеством печатной продукции / С. Ф. Гавенко // Полиграфическая промышленность : науч.-техн. информ. сб. ; НИЦ «Информпечать». - М., 1996. - Вып. 3. C. 6-9.

7. Гавенко С. Ф. Деякі аспекти оцінки якості друкованої продукції / С. Ф. Гавенко, О. В. Мельников // Наукові записки УАД : наук.-техн. зб. - 1999. Вип. 1. - С. 36.

8. Величко О. М. Тоновідтворення репродукцій за нейтрально-сірою шкалою / О. М. Величко, Я. В. Зоренко // Наукові записки : наук.-техн. зб. Львів : УАД, 2011. - № 3(36). - С. 262-268.

9. Шовгенюк М. В. Характеристики відбитків тріадних фарб у кольоровому просторі Adobe RGB / М. В. Шовгенюк, Н. В. Занько, Н. С. Писанчин // Комп'ютерні технології друкарства : зб. наук. праць. - Львів : УАД, 2007. № 19. - C. 203-222.

\section{References}

1. Poljanskij, N. N. \& Kartasheva, O. A. \& Nadirova, E. B. (2010). Tehnologija formnyh processov [Technology of plate processes]. Moscow: MGUP [in Russian].

2. Kartasheva, O. A. \& Busheva, E. V. \& Nadirova, E. B. (2013). Cifrovye tehnologii formnyh processov ploskoj ofsetnoj pechati [Digital technologies of plate processes of flat offset printing]. Moscow: MGUP [in Russian].

3. Gribkov, A. V. \& Tkachuk, Ju. N. (2010). Tehnika poligraficheskogo proizvodstva. Chast' 2. Dopechatnoe oborudovanie [Technique of printing production. Part 2. Prepress equipment]. Moscow: MGUP [in Russian].

4. ISO 12647-2: 2004 / Amd 1: 2007. Manage the production of color separeted halftone images, proof and run imprints. Part 2: Offset sheet printing [in English].

5. Horoshko, O. \& Kozak, O. (2000). Systema kontroliu yakosti drukarskoho protsesu [Quality control system of the printing process]. Journal of Palitra druku - Palette of printing, 6, 54-57 [in Ukrainian].

6. Havenko, S. F. (1996). Sistemotehnicheskij analiz i upravlenie kachestvom pechatnoj produkcii [System and technical analysis and quality management of printed products]. Journal of Poligraficheskaja promyshlennost' - Printing industry, 3, 6-9 [in Russian]. 
7. Havenko, S. F. \& Melnykov, O. V. (1999). Deiaki aspekty otsinky yakosti drukovanoi produktsii [Some aspects of the quality of printed products]. Journal of Naukovi zapysky UAD - Scientific papers of the UAP, 1, 36 [in Ukrainian].

8. Velychko, O. M. \& Zorenko, la. V. (2011). Tonovidtvorennia reproduktsii za neitralno-siroiu shkaloiu [Tone reproduction of reproductions on a neutral-gray scale]. Journal of Naukovi zapysky - Scientific notes, 3(36), 262-268 [in Ukrainian].

9. Shovheniuk, M. V. \& Zanko, N. V. \& Pysanchyn, N. S. (2007). Kharakterystyky vidbytkiv triadnykh farb u kolorovomu prostori Adobe RGB [Characteristics of the imprints of the triad colors in the color space Adobe RGB]. Journal of Komp'iuterni tekhnolohii drukarstva - Computer technologies of printing, 19, 203-222 [in Ukrainian].

В работе исследованы репродукционно-графические показатели печатных форм изготовленных по технологии CtP популярных марок, представленных на украинском рынке полиграфических расходных материалов. В результате исследований были построены графические зависимости, позволяющие оценить качество воспроизведения цветного изображения отпечатанного офсетным способом при заданных условиях и определить максимальное соответствие с оригиналом.

Ключевые слова: репродукционно-графические показатели; CtP; офсетная печать; офсетные пластины; цветное изображение.

In this study, the reproduction and graphic parameters of printing plates made by CtP technology of popular brands were investigated that are represented in the Ukrainian market of printing consumables. As a result of the research, graphic dependencies were built that allow estimation of the reproduction quality of color images in offset printing under given conditions and determine the maximum compliance with the original.

Keywords: reproduction and graphic parameters; CtP; offset printing; offset plates; color image.

Рецензент - О. В. Зоренко, к.т.н., доцент, КП। ім. Ігоря Сікорського 